\title{
Review
}

\section{Captives of sovereignty}

\author{
Jonathan Havercroft \\ Cambridge University Press, New York, 2011, viii+268 pp., \$103.00/£60, \\ ISBN: 978-1107012875
}

Contemporary Political Theory (2015) 14, e16-e18. doi:10.1057/cpt.2014.35;

published online 4 November 2014

Among key concepts of modern political thought, few have commanded as much fascination and proven as impervious to critique as sovereignty. Launched into modern political theory in the sixteenth and seventeenth centuries, sovereignty has become virtually unavoidable in the study of politics. So much has been written on the concept that it is a wonder anything original is left to be said. Yet the concept continues to captivate and new voices and interesting perspectives continue to emerge. Among recent publications on the topic, Jonathan Havercroft's Captives of Sovereignty is one of the more original.

Like many other contemporary theorists, Havercroft regards sovereignty as something to be overcome; he aspires for a post-sovereignty politics. What sets Havercroft's work apart, however, is that instead of merely focusing on the shortcomings of sovereignty per se, he attends to the underlying assumptions that make sovereignty seem indispensable in the first place. As the book title suggests, the author believes sovereignty is holding the study of politics captive; the terms of political discourse are set by the picture of the world divided into sovereign states. This is so despite scores of trenchant critiques. Captives of Sovereignty explores why.

The book's central contention is that sovereignty has resilience because it offers a principal response to modern skepticism. Critics' neglect of skepticism's challenges and their corresponding failure to provide alternative solutions has left sovereignty uncontested in this crucial domain. Captives of Sovereignty aims to rectify this by, first, exposing sovereignty's historical and theoretical entanglements with modern skepticism, and, second, using ordinary language philosophy to present an alternative set of responses. In this respect, Havercroft's argument is less a critique of sovereignty although he accepts many of the criticisms made by other authors, such as Foucault, Arendt, Agamben, and Hardt and Negri - and more an argument against skepticism and the ground it lays.

The book is organized into seven substantive chapters divided into two parts. Part 1 establishes connections between early theorizations of sovereignty and skeptical

(C) 2015 Macmillan Publishers Ltd. 1470-8914 Contemporary Political Theory Vol. 14, 3, e16-e18 www.palgrave-journals.com/cpt/ 
arguments about the groundlessness of knowledge, ethics and religion. Havercroft suggests that one of the sovereign's primary purposes is to resolve skeptical problems that creep into political life, including destabilizing effects on traditional forms of rule. Skepticism generates the expectation that criteria for adjudicating disputes should have objective grounding in clear authority structures. Skeptics regard the absence of such objective grounding in particular instances as implying the potential breakdown of social order more generally. This in turn provides the backdrop for sovereignty's development as a concept. Havercroft focuses his argument on the writings of Hobbes and Spinoza. In separate chapters on epistemic skepticism, ethical skepticism and religious skepticism, he carefully describes how concerns over skepticism infuse Hobbes's and Spinoza's arguments. For them, sovereignty solves the skeptic's problems by imposing adjudicatory criteria through fiat - the sovereign decides, and, by deciding, the sovereign generates order over chaos. These chapters are interesting studies in their own right in that they bring a fresh perspective to bear on two canonical figures of political theory. In the book's larger argument, they function to lay out a problem for which the book's second part provides the solution. As Havercroft writes, 'sovereignty appears to be the necessary, universal, and obligatory foundation of modern political thought because in its absence all the skeptical challenges to knowledge and society re-emerge' (p. 147). Unless we can tackle the problems of skepticism, we won't be able to get around the need for sovereignty.

In Part 2, Havercroft pivots away from Hobbes and Spinoza and turns to twentieth century ordinary language philosophers to forge an alternative response to skepticism. Drawing especially from Wittgenstein's Philosophical Investigations and the writings of Stanley Cavell, he argues that skepticism tends to generate pseudo-problems by abstracting out of the everyday contexts that provide meaning. The political blackmail of the skeptic is that the absence of objective grounding for criteria to adjudicate disputes in particular circumstances is interpreted as if there are no criteria and no grounding at all. The sovereign becomes necessary when we believe there has to be some sort of transcendent authority to ground criteria if we are to avoid social breakdown. For Havercroft, this is the wrong way to frame the issue. In ordinary life situations, criteria do exist for resolving disputes without authoritarian fiat or resort to a final arbiter (p. 174). Such criteria are not rooted in transcendental authority structures but rather in the community of language speakers who exercise authority by making claims within intersubjective language games.

With distinct chapters, Havercroft carries these insights into discussions of democratic theory and international relations (IR). He uses Cavell to critique popular sovereignty both as it was first conceived by Rousseau and as it has been adapted by Habermas and other contemporary theorists. The thrust of his argument in both cases is that popular sovereignty harbors transcendental dimensions and dominating tendencies that are both unnecessary and dangerous. A radical democratic ethos, at times fleeting, percolates through parts of Havercroft's text. It gets expressed in 
concern that sovereignty leads to the evasion of responsibility for knowledge claims, the usurpation of political voice and the undermining of citizens' ability to challenge one another (p. 177). Havercroft openly adopts what he calls a 'non-transcendental and non-foundational approach that grounds values in our everyday forms of life' (p. 195). Contra Habermas, he argues that everyday forms of life are flexible enough to avoid social conformism without the need for transcendental reason, and, contra conservatives, he believes the grammar of everyday practices are stable enough to avoid nihilism.

In his final substantive chapter, Havercroft returns to where he started - IR and the image of the world divided into sovereign states. He creatively likens IR's security dilemma to the 'other mind problem' in philosophy. Both involve epistemic uncertainty about a counterpart's thoughts, and both unduly abstract away from everyday situations in which we actually do know enough about rivals' intentions to avoid worst case scenarios. He also draws parallels between IR debates about international ethics and philosophical debates about ethical relativism. Like relativist arguments, realist arguments that deny international ethics end up implicitly assuming international community as a background source of meaning and shared values. The books' overall message is that many of the problems sovereignty is meant to solve amount to pseudo-problems once we attend to actual conditions and everyday political contexts.

By bringing together IR theory, political theory and linguistics, Captives of Sovereignty offers a novel take on sovereignty. It makes a compelling case that early theorizations of sovereignty were at least partially intended to address skeptical challenges to authority. And it offers some new ways of thinking about why sovereignty remains so captivating a concept. More critically, Havercroft does tend to overstate the centrality of epistemic uncertainty to sovereignty arguments. Although he acknowledges that theories of sovereignty are not only concerned with refuting philosophical skepticism (p. 54), he gives little attention to force and physical violence. He convincingly argues that epistemic uncertainty and value pluralism needn't entail the sort of complete social breakdown often used to justify sovereignty, but he does little to suggest what can be done in lieu of sovereignty when such breakdowns - which are physical and not merely epistemic - occur. When he does address such breakdowns, it is often with elliptical references to 'anarchy', which serves as a trope for social disruption generally. This is unfortunate given how little it says about actual social breakdown and given that such a vision of anarchy is itself a distorted abstraction away from everyday contexts. This is also a missed opportunity considering the ways that anarchist theory and practice otherwise resonate with Havercroft's anti-foundational, non-transcendental, non-hierarchical, participatory, post-sovereignty politics rooted in everyday life. These are, nevertheless, minor criticisms of an otherwise insightful and carefully executed book.

Craig Borowiak

Haverford College, Haverford, PA 19041, USA 